\section{In Vitro Synthesis of Novel Genes: Mutagenesis and Recombination by PCR}

\author{
Abbe N. Vallejo, \\ Robert J. Pogulis, \\ and Larry R. Pease
}

Department of Immunology, Mayo Clinic/Foundation, Rochester, Minnesota 55905
Since its description, $\mathrm{PCR}^{(1)}$ has become a fundamental analytical tool in cellular and molecular biology. The literature is replete with the use of this technique in the identification of new genes or members of gene families, even those from distantly related species. PCR permitted the introduction of mutations into DNA sequences ${ }^{(2)}$ to allow assessment of the biological function of genes. PCR can also be used to simplify site-directed mutagenesis and to generate recombinant or chimeric gene constructs. ${ }^{(3,4)}$ Mutagenesis by PCR is accomplished by incorporating the desired genetic changes in custommade primers used in amplification reactions. Because these mutagenizing primers have terminal complimentarity, two separate DNA fragments amplified from a target gene may be fused into a single product (see below) by primer extension without relying on restriction endonuclease sites or ligation reactions.

The relative ease of rapidly combining two DNA fragments by overlap extension led to its application in the production of chimeric genes. As long as pairs of primers used in amplification reactions have complementary terminal regions, overlapping strands of PCR-amplified DNA fragments from various sources may be spliced together by the extension of overlapping strands (hence, the term splicing by overlap extension or gene SOEing) in a subsequent reaction. The ability to generate genetic recombinants by SOEing is limited only by the knowledge of the mechanisms of folding and/or assembly of the encoded novel protein when transfected into cells. SOE has been used routinely to generate mutant molecules, complex hybrid genes, engineer proteins, and to create mutant libraries. ${ }^{(5-15)}$

\section{THE CONCEPT OF OVERLAP EXTENSION}

Overlap extension uses PCR both for introducing site-specific mutations and for generating recombinant gene constructs. Details of the strategy have been described previously. ${ }^{(3,4)}$ Briefly, mutagenesis is achieved by PCR with the use of specially designed oligonucleotide primers that include in their sequence the desired changes (i.e., substitutions, insertions, or deletions) to be incorporated in the gene construct (Fig. 1). Because the mutagenizing primers also have terminal complementarity, two overlapping fragments can be fused together in a subsequent extension reaction. Inclusion of outside primers in the extension reaction amplifies the fused product by PCR. In principle, the position of the primers may be moved anywhere along the targeted gene to introduce mutations. Thus, the region of the gene containing the introduced mutations may be lengthened in a single reaction.

The ability to fuse two DNA fragments by overlap extension can be exploited further to splice (or SOE together) two or more DNA fragments from different genes to generate a chimeric product. Like the mutagenizing primers, SOEing primers have terminal complementarity; thus DNA fragments generated by PCR can be spliced together by primer extension and amplified to yield a recombinant product (Fig. 2).

A limitation of the SOE technique, however, is the difficulty of manipulating large DNA segments, that is, those $>1-2 \mathrm{~kb}$. To circumvent this difficulty, a cassette system may be developed wherein shorter DNA segments, typically $\sim 500-1000 \mathrm{bp}$, can be easily targeted, modified by SOE, and reinserted using restriction endonuclease sites designed into the cassette structure. $^{(4,5)}$ Thus, specific segments of genes can be manipulated at will. This cassette approach also allows for the easy shuffling or replacements of gene segments. Such a cassette system has been a very valuable tool in dissecting the structure-function relationship of class I major histocompatibility complex (MHC) molecules. ${ }^{(4-10)}$ 


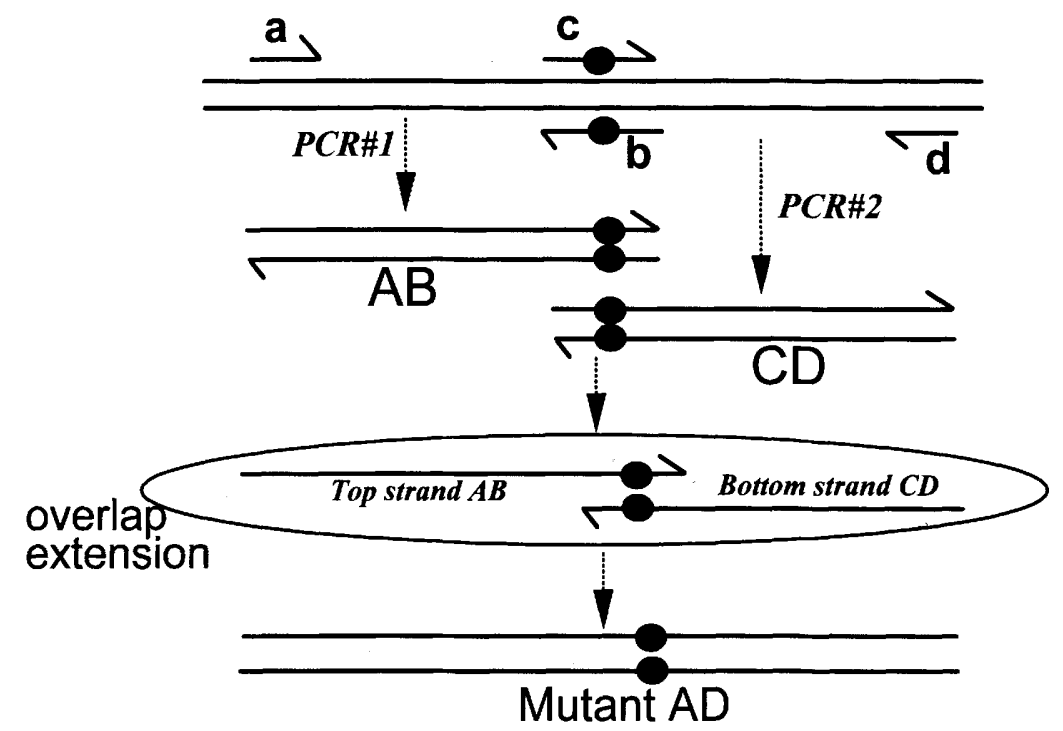

FIGURE 1 Mutagenesis by overlap extension. Two segments of a gene are amplified by PCR independently and then fused together in a subsequent reaction. Mutations are introduced into a targeted region with the use of specially designed mutagenizing primers $(b, c)$ which contain nucleotide mismatches $(\mathbf{)})$ in the center of the primers. Because these primers are complementary, strands of PCR products generated independently with these primers will have an overlap that can be extended in a subsequent reaction to form the mutant product. When outside primers $(a, d)$ are added to this latter reaction, the fused mutant product is amplified as soon as it is formed.

\section{DESIGN OF OLIGONUCLEOTIDE PRIMERS}

SOEing oligomers have two sequence regions, namely, a priming region and an overlap region. The priming region is the $3^{\prime}$ end of the oligomer, which serves as the PCR primer, while the overlap region is the $5^{\prime}$ end of the oligomer, which is complimentary to a sequence of a DNA fragment that will be fused with it in the overlap extension reaction. As depicted in Figure 2, primer $x$ contains a priming sequence for the amplification of gene 1 and also has an overlap sequence at its $5^{\prime}$ end that is complimentary to a segment of gene 2 .

Mutagenizing oligomers can have their priming and overlap regions completely coinciding with each other. The center of the oligomers contain the mismatches or deletions that will be incorporated by overlap extension (Fig. 1).

In designing the oligomers, actual lengths of the priming and overlap regions may depend on the particular situation. One approach is to determine the length by a simple estimate of the melting temperature, ${ }^{(16,17)}$ which is calculated as follows: $T_{\mathrm{m}}=[(\mathrm{G}+\mathrm{C}) \times 4]+[(\mathrm{A}+\mathrm{T}) \times 2]$. This quantity is an estimate of the denaturation temperature $\left(\right.$ in $\left.{ }^{\circ} \mathrm{C}\right)$ of the oligomer. As a rule of thumb, our oligomers are designed such that both their priming and overlap regions have $T_{\mathrm{m}} \sim 50^{\circ} \mathrm{C}$. This $50^{\circ} \mathrm{C}$ rule generally gives a length estimate of 13-20 bp for both the priming and the overlap regions of the oligomers. The mismatches incorporated in mutagenizing oligomers are not included in this estimation.

It must be emphasized, however, that melting temperature does not estimate accurately the annealing temperature of any specific oligomer because it does not take into consideration the concentration of salts present in the cycling reaction. Nevertheless, our $50^{\circ} \mathrm{C} T_{\mathrm{m}}$ rule has usually yielded reliable oligomers that anneal at this temperature.

The usual rules in designing PCR primers apply when synthesizing SOEing and mutagenizing primers. ${ }^{(16,18)}$ Oligomer sequences must always be checked for their potential to form secondary structures and for complementarity to 


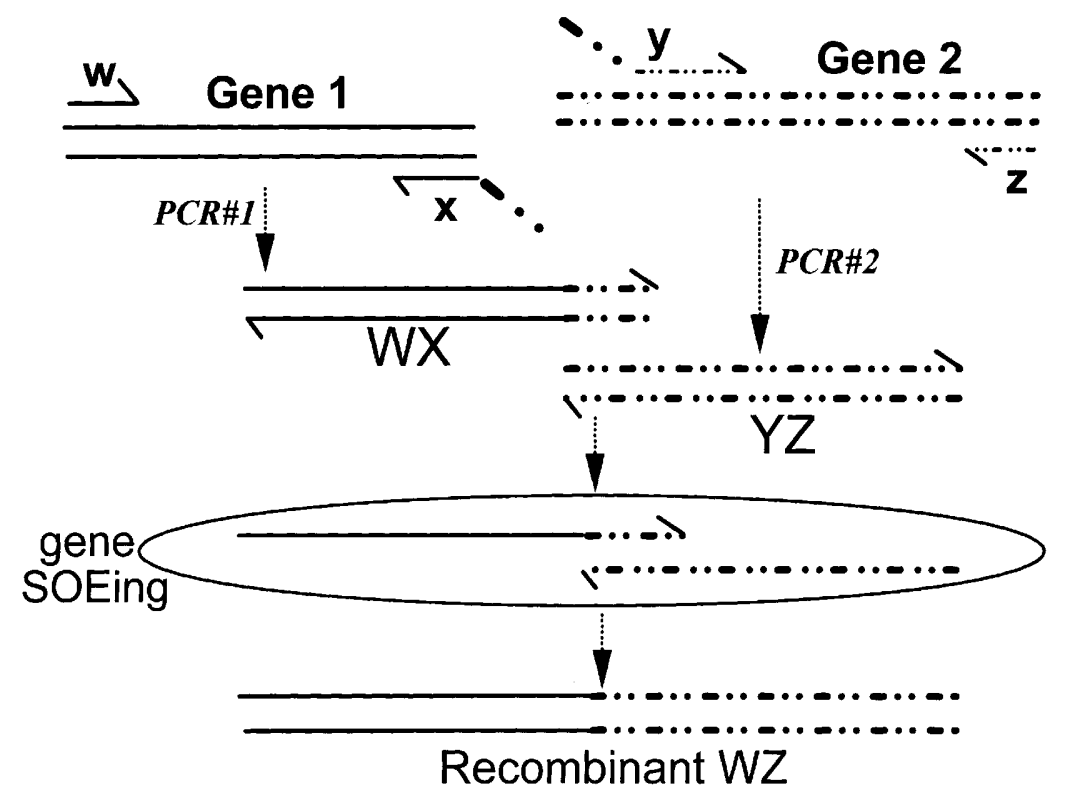

FIGURE 2 Gene SOEing. The reaction involved in SOEing is similar to that depicted in Fig. 1, with two exceptions: (1) The PCR products to be fused are derived from two different genes; and (2) the fusion is mediated by an overlap of the two strands of PCR products that were created with the use of SOEing primers $(x, y)$. In this case, the $5^{\prime}$ region of primer $x$, used in the amplification of gene 1 , is complimentary to a segment of gene 2 (i.e., 5 ' region of primer $y$ ). A recombinant product is therefore formed when this overlap is extended in a subsequent reaction, and this recombined product may be amplified with the inclusion of outside primers $(w, z)$ in this latter extension reaction.

primers in the same reaction. Proper priming is achieved when at least the five bases of the $3^{\prime}$-terminal end of the primer are complementary to the template. Introducing mismatches too close to the $3^{\prime}$ end of the primer could result in the lack of amplification.

\section{PROCEDURES}

\section{Materials and Reagents}

1. Thermal cycling (PCR) machine.

2. Taq DNA polymerase (Perkin-Elmer Cetus, Norwalk, CT).

3. $10 \times$ PCR buffer containing $100 \mathrm{~mm}$ Tris $(\mathrm{pH} 8.3), 500 \mathrm{mM} \mathrm{KCl}$, and 10 mм $\mathrm{MgCl}_{2}$ (see Note 4, below, for determining appropriate concentration of $\mathrm{Mg}^{2+}$ ).

4. $10 \times$ dNTPs: Prepare a $2 \mathrm{~mm}$ stock $(10 \times)$ solution of each of the dNTPs. It is important to mention that the $\mathrm{pH}$ of the solution must be adjusted to 7.5 , otherwise polymerase activity will be inhibited. This $\mathrm{pH}$ adjustment is not necessary when using commercially available dNTP solutions (Pharmacia LKB, Uppsala, Sweden) that are ready made as aqueous stocks with the correct $\mathrm{pH}$.

5. Mineral oil (Sigma, St. Louis, MO).

6. Sterile water (Baxter, Deerfield, IL).

7. Amplification tubes: Microcentrifuge tubes that fit into the heating block of the PCR machine (refer to the manufacturer's instructions).

8. Agarose: The concentration of agarose needed to resolve DNA fragments depends on the fragment size to be isolated. In our experience, $0.8-1 \%$ agarose is generally satisfactory in resolving DNA fragments from $100 \mathrm{bp}$ to $2 \mathrm{~kb}$. Greater resolution also may be achieved by mixing ultragrade agaroses like 
NuSieve with the less expensive "working" agaroses like LE or SeaKem agarose (FMC BioProducts, Rockland, ME).

9. Agarose gel electrophoresis units and supplies.

10. GeneClean or Mermaid Kits (Bio101 Inc., La Jolla, CA) or electroelution apparatus (see Note 5, below).

Protocol 1: PCR Mutagenesis by Overlap Extension

1. Set up the PCR reactions to produce products $\mathrm{AB}$ and $\mathrm{CB}$ (refer to Fig. 1) in individual microcentrifuge tubes.

Reaction no. 1 2

\begin{tabular}{lll}
\hline PCR product & $\mathrm{AB}$ & $\mathrm{CD}$ \\
Template & parental template & parental template \\
$5^{\prime}$ primer & $\mathrm{a}$ & $\mathrm{c}^{*}$ \\
$3^{\prime}$ primer & $\mathrm{b}^{*}$ & $\mathrm{~d}$ \\
10× PCR buffer & $10 \mu \mathrm{l}$ & $10 \mu \mathrm{l}$ \\
$10 \times$ dNTPs & $10 \mu \mathrm{l}$ & $10 \mu \mathrm{l}$ \\
Taq polymerase & 2.5 units & $2.5 \mathrm{units}$ \\
Sterile water & to $100 \mu \mathrm{l}$ & to $100 \mu \mathrm{l}$ \\
\hline
\end{tabular}

$\left.{ }^{\star}\right)$ Mutagenizing primers.

2. Overlay the PCR mixture with $2-3$ drops of mineral oil.

3. Cycle for $15-25$ rounds $\left(30 \mathrm{sec}\right.$ at $94^{\circ} \mathrm{C}, 2 \mathrm{~min}$ at $50^{\circ} \mathrm{C}, 1 \mathrm{~min}$ at $72^{\circ} \mathrm{C}$ ).

4. Run the entire reactions on agarose gels.

5. Cut out the bands of interest (i.e., products $A B$ and $C D$ ), and recover the DNA fragments by GeneClean, Mermaid, electroelution, or the freezesqueeze technique (see Note 5 , below).

6. Set up the overlap extension reaction in a new microcentrifuge tube.

Product

$\mathrm{AD}$

$\begin{array}{ll}\text { Template } 1 & \mathrm{AB} \\ \text { Template } 2 & \mathrm{CD} \\ 5^{\prime} \text { primer } & a \\ 3^{\prime} \text { primer } & d \\ \text { 10× PCR buffer } & 10 \mu \mathrm{l} \\ 10 \times \text { dNTPs } & 10 \mu \mathrm{l} \\ \text { Taq polymerase } & 2.5 \text { units } \\ \text { Sterile water } & \text { to } 100 \mu \mathrm{l}\end{array}$

This reaction is not very sensitive to the amounts of templates added. Typically, 10-100 ng of each template may be used. Primers $a$ and $d$ may also be added from the beginning of this PCR reaction. Alternatively, three to five cycles of extension can be carried out first to allow for the formation of the mutant product $\mathrm{AD}$ followed by amplification upon addition of the primers.

7. Overlay reaction mixture with mineral oil and amplify by PCR as in 3 , above.

8. Run reaction on agarose gels, cut out the band of interest (i.e., product $\mathrm{AD}$ ), and recover DNA fragment as in 5, above.

9. The purified mutant product $\mathrm{AD}$ may then be digested with the appropriate restriction enzymes and ligated to an appropriate cloning vector for subsequent transformation and sequencing (see Note 6, below).

\section{Protocol 2: Gene SOEing}

1. Set up PCR reactions in individual microcentrifuge tubes to generate products WX and YZ from genes 1 and 2, respectively (Fig. 2). 


\begin{tabular}{lll} 
Reaction no. & \multicolumn{1}{c}{1} & \multicolumn{1}{c}{2} \\
\hline PCR product & WX & YZ \\
Template & gene 1 & gene 2 \\
$5^{\prime}$ primer & $\mathrm{W}$ & $\mathrm{y}^{*}$ \\
3' primer & $\mathrm{X}^{*}$ & $\mathrm{Z}$ \\
$10 \times$ PCR buffer & $10 \mu \mathrm{l}$ & $10 \mu \mathrm{l}$ \\
$10 \times$ dNTPs & $10 \mu \mathrm{l}$ & $10 \mu \mathrm{l}$ \\
Taq polymerase & $2.5 \mathrm{units}$ & $2.5 \mathrm{units}$ \\
Sterile water & to $100 \mu \mathrm{l}$ & to $100 \mu \mathrm{l}$ \\
\hline
\end{tabular}

$\left({ }^{*}\right)$ SOEing primers.

2. Overlay the reaction with 2-3 drops of mineral oil.

3. Cycle for $15-25$ rounds $\left(30 \mathrm{sec}\right.$ at $94^{\circ} \mathrm{C}, 2 \mathrm{~min}$ at $50^{\circ} \mathrm{C}, 1 \mathrm{~min}$ at $72^{\circ} \mathrm{C}$ ).

4. Run the entire reactions on agarose gels.

5. Cut out the bands of interest (i.e., products $W X$ and $Y Z$ ), and recover the DNA fragments by GeneClean, Mermaid, electroelution, or the freezesqueeze technique (see Note 5 , below).

6. Set up the SOEing reaction in a new microcentrifuge tube.

Product

Template 1

Template 2

$5^{\prime}$ primer

3' primer

$10 \times$ PCR buffer

$10 \times$ dNTPs

Taq polymerase Sterile water
WZ

\begin{tabular}{l}
$\mathrm{WX}$ \\
$\mathrm{YZ}$ \\
$\mathrm{W}$ \\
$\mathrm{Z}$ \\
$10 \mu \mathrm{l}$ \\
$10 \mu \mathrm{l}$ \\
2.5 units \\
to $100 \mu \mathrm{l}$ \\
\hline
\end{tabular}

7. Overlay reaction mixture with mineral oil and PCR amplify as in 3 , above.

8. Run the entire reaction on agarose gels, cut out the band of interest (i.e., product WZ), and recover DNA fragment as in 5, above.

9. The purified recombinant product $\mathrm{WZ}$ may then be digested with the appropriate restriction enzyme and ligated to an appropriate cloning vector for subsequent transformation and sequencing (see Note 6, below).

\section{NOTES/COMMENTS}

\section{Oligonucleotide Purification}

Oligomers used in this laboratory are synthesized using an Applied BioSystems DNA Synthesizer (Foster City, CA) in our institutional core facility, and the final material comes as an aqueous ammonia solution. The solution is dried under vacuum (SpeedVac SC100, Savant, Inc., Farmingdale, NY). The residue is resuspended in $1 \mathrm{ml}$ of sterile water and desalted in Sephadex G-25 (NAP-10 columns, Pharmacia LKB Biotech, Uppsala, Sweden). Fractions of 500 $\mu l$ are collected, and the absorbance of each fraction is determined at $260 \mathrm{~nm}$. The fractions containing the first peak are pooled (typically fractions 3-5 from NAP-10 columns), and absorbance is measured at 260 and $300 \mathrm{~nm}$. The concentration of the purified oligomer is determined by the following formula: $\mu \mathrm{g} / \mathrm{ml}=\left(A_{260}-A_{300}\right) \times$ dilution factor $\times 33$, where the number 33 is the approximate concentration of oligonucleotides $(\mu \mathrm{g} / \mathrm{ml})$ per unit of absorbance at $260 \mathrm{~nm} .{ }^{(19)}$ Concentration of the stock oligomer may also be expressed in molar terms as follows: $\mu \mathrm{M}=\left(\left[\left(A_{260}-{ }_{300}\right) \times\right.\right.$ dilution fac- 


\section{Manual Supplement IIIII}

tor $] \div \epsilon 260) \times 10^{6}$, where $\epsilon 260$, the extinction coefficient, equals the number of bases times 10,000 . The purified oligomer is aliquoted into smaller quantities and stored at $-20^{\circ} \mathrm{C}$.

\section{Primer Concentration}

In a standard reaction of $100 \mu$ l, we find that 100 pmoles of each primer is optimal. This gives a final concentration of $1 \mathrm{pmole} / \mu \mathrm{l}$ (or $1 \mu \mathrm{M}$ ). It is recommended, however, that the amounts of primers be determined empirically. The important point to consider is that large amounts of primers increase amplification errors caused by mispriming.

\section{Template Concentration}

In theory, larger amounts of template reduce the number of cycles required to generate enough product and, therefore, lessen the chance of Taq polymerase-induced base misincorporations. However, high concentrations of template tend to impede successful amplification, and fewer rounds of amplification produce more open-ended strands (i.e., single-stranded products that extend beyond the length of the primer) that contribute to the background. Thus, it is necessary to titrate the amount of template to determine the optimal concentration. We generally find that $500 \mathrm{ng}$ of cloned template or as much as 1-2 $\mu \mathrm{g}$ of genomic DNA yield the PCR products of interest without significant background amplification.

\section{Magnesium Concentration}

Perhaps the single most important parameter for PCR is the amount of $\mathrm{Mg}^{2+}$ present in the amplification reaction. High concentrations of $\mathrm{Mg}^{2+}$ generally produce background amplification and increase Taq-induced errors that can be reduced by lowering the amount of $\mathrm{Mg}^{2+}$ in the reaction. Therefore, the optimal concentration of $\mathrm{Mg}^{2+}$ must be first determined. Experimental protocols involving PCR begin with ascertaining optimal amplification conditions. Stocks of $10 \times$ PCR buffers are prepared containing various concentrations of $\mathrm{MgCl}_{2}$, which, when used at $1 \times$ concentration, give a final concentration of $0.5-2.5 \mathrm{mM}$ of $\mathrm{Mg}^{2+}$. In most of our PCR experiments, we find that $1 \mathrm{mM} \mathrm{Mg}^{2+}$ is optimal.

\section{Purification of PCR and SOEing Products}

Agarose gel purification of the intermediate PCR products leads to cleaner SOE reactions. ${ }^{(3)}$ This purification step removes templates as well as openended strands that could potentially generate unwanted products. Similarly, gel purification of SOE products ensures cleaner fragments for subsequent cloning.

Depending on the size of the DNA fragments, amplification products may be purified by either GeneClean or Mermaid kits (Bio101 Inc., La Jolla, CA). The latter is specifically designed for the purification of products $\leqslant 200 \mathrm{bp}$. Alternatively, purification may also be achieved by electroelution ${ }^{(19)}$ or by a modification of the freeze-squeeze technique. ${ }^{(20)}$

To purify DNA by the freeze-squeeze method, the band of DNA fragment of interest is excised from an agarose gel, macerated, transferred to a microcentrifuge tube, and frozen at $-70^{\circ} \mathrm{C}$ for $1 \mathrm{hr}$ (or overnight at $-20^{\circ} \mathrm{C}$ ). The frozen gel is thawed at $37^{\circ} \mathrm{C}$ for $1 \mathrm{hr}$, transferred to an Ultrafree-MC filter unit (Millipore, Bedford, MA) or a Spin-X filter unit (Costar, Cambridge, MA), and centrifuged at $14,000 \mathrm{rpm}$ for $20 \mathrm{~min}$ at room temperature. The filtrate is collected and subjected to two rounds of ethanol precipitation. ${ }^{(19)}$ 


\section{Cloning and Sequencing of SOEing Products}

Mutant and/or recombinant genes generated by SOE must always be cloned and sequenced to determine accuracy of the introduced genetic changes as well as to ascertain that there have been no amplification errors. We routinely sequence DNA using the Sequenase kit (U.S. Biochemical, Cleveland, OH) or by an automated sequencer (Applied BioSystems Sequencer model 373A, Perkin-Elmer Cetus, Norwalk, CT).

Cloning of the PCR-generated genes could be facilitated by designing amplification primers (i.e., $a-b$ and $w$-z primer pairs in Figs. 1 and 2, respectively) with unique flanking restriction enzyme sites (details of the strategy are discussed elsewhere). ${ }^{(21)}$ The product of the third PCR reaction (mutant AD or recombinant $\mathrm{WZ}$ ) may then be digested with these enzymes and cloned into a suitable vector or exchanged with the appropriate fragment of a plasmid cassette. $^{(4,5)}$

\section{REFERENCES}

1. Mullis, K., F. Faloona, S. Scharf, R. Sakali, G. Horn, and H. Erlich. 1986. Specific enzymatic amplification of DNA in vitro: The polymerase chain reaction. Cold Spring Harbor Symp. Quant. Biol. 51: 263-273.

2. Higuchi, R., B. Krummel, and R.K. Sakai. 1988. A general method of in vitro preparation and specific mutagenesis of DNA fragments: Study of protein and DNA interactions. Nucleic Acids Res. 15: 7351-7367.

3. Ho, S.N., H.D. Hunt, R.M. Horton, J.K. Pullen, and L.R. Pease. 1989. Site-directed mutagenesis by overlap extension using polymerase chain reaction. Gene 77: 51-59.

4. Horton, R.M., Z. Cai, S.N. Ho, and L.R. Pease. 1990. Gene splicing by overlap extension: Tailor-made genes using the polymerase chain reaction. BioTechniques 8: 528-535.

5. Hunt, H.D., J.K. Pullen, Z. Cai, R.M. Horton, S.N. Ho, and L.R. Pease. 1990. Novel MHC variants spliced by overlap extension. In Transgenic mice and mutants in $\mathrm{MHC}$ research (ed. I.K. Egorov and C.S. David), pp. 47-55. Springer-Verlag, Berlin, Germany.

6. Hunt, H.D., J.K. Pullen, R.F. Dick, J.A. Bluestone, and L.R. Pease. 1990. Structural basis of $K^{\mathrm{bm} 8}$ alloreactivity: Amino acid substitutions on the $\beta$-pleated floor of the antigen recognition site. J. Immunol. 145: 1456-1462.

7. Pullen, J.K., H.D. Hunt, and L.R. Pease. 1991. Peptide interactions with the $\mathrm{K}^{\mathrm{b}}$ antigen recognition site. J. Immunol. 146: 2145-2151.

8. Pease, L.R., R.M. Horton, J.K. Pullen, H.D. Hunt, T.J. Yun, E.M. Rohren, J.L. Prescott, S.M. Jobe, and K.S. Allen. 1993. Amino acid changes in the peptide binding site have structural consequences at the surface of class I glycoproteins. I. Immunol. 150: 3375-3381.

9. Yun, T.J., M.D. Tallquist, E.M. Rohren, J.M. Sheil, and L.R. Pease. 1994. Minor pocket B influences peptide binding, peptide presentation and alloantigenecity of $\mathrm{H}-2 \mathrm{~K}^{\mathrm{b}}$. Int. Immunol. 6: 1037-1047.

10. Cai, Z. and L.R. Pease. 1992. Structural and functional analysis of three D/L-like class I molecules from H-2 ${ }^{\mathrm{v}}$ : Indications of an ancestral family of D/L genes. J. Exp. Med. 175: 583596.

11. Gobius, K.J., S.W. Rowlinson, R. Barnard, J.S. Mattick, and M.J. Waters. 1992. The first disulfide loop of the rabbit growth hormone receptor is required for binding to the hormone. J. Mol. Endocrinol. 9: 213-220.

12. Bobek, L.A., H. Tsai, and M.J. Levine. 1993. Expression of human salivary histatin and cystatin/histatin chimeric cDNAs in Escherichia coli. Crit. Rev. Oral Biol. Med. 4: 581-590.

13. Kirchoff, F. and R.C. Desrosiers. 1993. A PCR-derived library of random mutations within the V3 region of simian immunodeficiency virus. PCR Methods Applic. 2: 301-304.

14. Davis, G.T., W.D. Bedzyk, E.W. Voss, and T.W. Jacobs. 1991. Single chain antibody (SCA) encoding genes: One step construction and expression in eukaryotic cells. BioTechnology 9: 165-169.

15. Daugherty, B.L., J.A. deMartino, M.F. Law, D.W. Kawka, I.I. Singer, and G.E. Mark. 1991. Polymerase chain reaction facilitates the cloning, CDR-grafting and rapid expression of a murine monoclonal antibody directed against the CD18 component of leukocyte integrins. Nucleic Acids Res. 19: 2471-2476.

16. Horton, R.M. and L.R. Pease. 1991. Recombination and mutagenesis of DNA sequences using PCR. In Directed mutagenesis: A practical approach (ed. M.J. McPherson), pp. 217-247. Oxford University Press, Oxford, UK.

17. Suggs, S.V., T. Hirose, T. Miyaki, E. Kawashima, M.J. Johnson, K. Itakura, and R.B. Wallace. 1981. Use of synthetic oligodeoxyribonucleotides for the isolation of cloned DNA sequences. In Developmental biology using purified genes (ed. D.D. Brown and C.F. Fow), pp. 683-693. 


\section{Manual Supplement IIIII}

Academic Press, NY.

18. Rychlik, W. 1993. Selection of primers for polymerase chain reaction. In Methods in molecular biology, PCR protocols: Current methods and applications, vol. 15 (ed. B.A. White), pp. 31-40. Humana Press, Totowa, NJ.

19. Sambrook, J., E.F. Fritsch, and T. Maniatis. 1989. Molecular cloning: A laboratory manual, 2nd ed., pp. 6.28-6.29; E.10-E.15. Cold Spring Harbor Laboratory Press, Cold Spring Harbor, New York.

20. Tautz, D. and M. Renz. 1983. An optimized freeze-squeeze method for the recovery of DNA fragments from agarose gels. Anal. Biochem. 132: 14-19.

21. Kwok, S., S.Y. Chang, J.J. Sninsky, and A. Wang. 1994. A guide to the design and use of mismatched and degenerate primers. PCR Methods Applic. 3: S39-S47. 


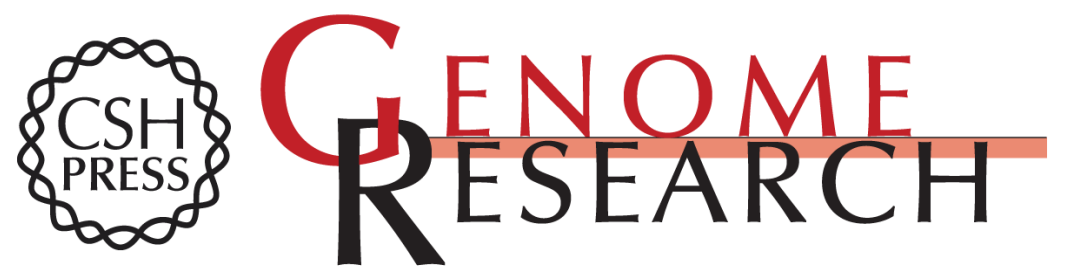

\section{In vitro synthesis of novel genes: mutagenesis and recombination by PCR.}

A N Vallejo, R J Pogulis and L R Pease

Genome Res. 1994 4: S123-S130

References This article cites 16 articles, 6 of which can be accessed free at: http://genome.cshlp.org/content/4/3/S123.full.html\#ref-list-1

License

Email Alerting

Receive free email alerts when new articles cite this article - sign up in the box at the Service top right corner of the article or click here.

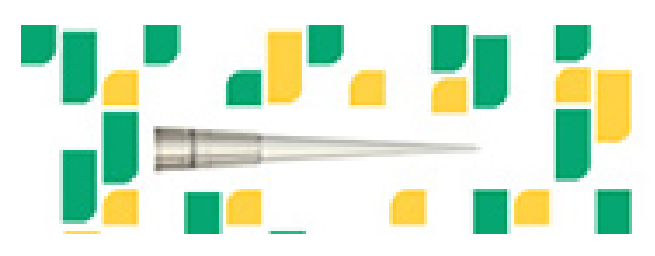

To subscribe to Genome Research go to: https://genome.cshlp.org/subscriptions 